\title{
Adolescent Cannabis Use - a Young Adult and Middle Age Urologic and Reproductive Dilemma: The Niger Delta Malady
}

\author{
H A A Ugboma ${ }^{1, *}$, H L Aburoma², P Ukaigwe ${ }^{2}$ \\ ${ }^{1}$ Department of Obstetrics and Gynaecology, University of Port Harcourt, Nigeria \\ ${ }^{2}$ Department of Nursing, University of Port Harcourt, Nigeria
}

\begin{abstract}
The sudden affluence in the Niger delta area of Nigeria due to the oil and gas industry, brought with it certain vices like the increasing use of Cannabis (Marijuana) by its younger population. This exposure to Cannabis has increased the incidence in urological and reproductive pathologies. Frequent marijuana use significantly increase testicular cancer risk and several urologic dysfunctions. This study clinically investigates the epidemiological evidence on the major adverse health effects of cannabis use and the link associated with urological dysfunctions and considers its implications for policy. A cross-sectional sample of 2290 males attending urology primary care clinics and inpatients in healthcare institutions in the Niger Delta Region was undertaken, 75 of the cases were included in the randomized follow-up study from March 2009 to March 2011. Those who use marijuana weekly or who have had exposure to marijuana since adolescents had twice the cancer risk, erectile and infertile anomalies, when compared to men who never smoked marijuana. Cannabis use was associated with urological dysfunctions like erectile dysfunctions, infertility and testicular cancer.
\end{abstract}

Keywords Adolescent/Male Health, Marijuana Use, Infertility, Testicular Cancer

\section{Introduction}

Urologic dysfunctions especially testicular cancer and male infertility have more than doubled over the past 30 years and its rise parallels the use of cannabis, the global most popular illegal drug[1]. The adverse health effects of cannabis have been a source of controversy in debates about policies towards the drug, while it has been evidenced that chronic marijuana use produces adverse effects on the human endocrine and reproductive systems[2]. The incidence of urologic anomalies and the use of marijuana in the sub Saharan Africa continue to rise to alarming levels, which is one of the several factors that led the researchers to hypothesize a potential association. The testicles are one of the few organs in the body that have receptor sites for cannabinoids, the active ingredient in marijuana[3]. The testes have receptors for tetrahydrocannabinol (THC), the main psychoactive ingredients in cannabis, and the male reproductive system is known to naturally produce a cannabinoid-like chemical that is thought to protect against reproductive and urologic diseases[4]. Scholarly research articles postulate that cannabis may interfere with this anti-tumor effect,

\footnotetext{
* Corresponding author:
}

haugboma@yahoo.co.uk (H A A Ugboma)

Published online at http://journal.sapub.org/ajmms

Copyright (C) 2012 Scientific \& Academic Publishing. All Rights Reserved increasing the risk of urologic dysfunctions similar to cancer developing[5]. Chronic Cannabis use is known to reduce sperm quality and induce fertility problems (low testosterone, increase impotence and erectile dysfunctions)[6]. A stronger literature has identified an association between marijuana use and carcinogenesis[5]. Clinical screening and program interventions for adolescents have potential to prevent marijuana use and the adverse effects.

\section{Materials and Methods}

A cross-sectional sample of 2290 males attending urology primary care clinics and inpatients in healthcare institutions in the Niger Delta Region was undertaken, 75 of the cases were included in the randomized follow-up study from March 2009 to March 2011 in six primary, six secondary, and four tertiary hospitals. Among the men screened, 40 presented with the signs and symptoms of testicular cancer, infertility and erectile dysfunctions and are marijuana smokers, these formed the intervention group; while 35 presented with benign carbuncles and rashes to the testes and did not smoke marijuana, and they formed the control group.

Setting:

The Niger Delta Region is a major precinct in the South-southern geopolitical zone within Nigeria. It is also among the world's major wetlands; with one of the largest mangrove ecosystems and a major territory of the global 
diversified industrial activities related to oil and gas exploration, which attract agglomeration of emigrants. There are two main 'temperature seasons, the rainy season, so named because there is a lot of rain, which usually lasts from about May until September. The dry season, so named because there is not much rain and lasts to the remainder of the year. A period around December till January called the Harmattan season, during which it gets cold and dry, sometimes cold enough to need a sweater.

\subsection{Ethical Approval and Consent}

Prior to commencement of interview, standardized description of goals and procedure of study, data uses and protection and rights of respondents were provided in both written and verbal form to all predesignated respondents before obtaining informed and verbal consent for participating in the survey. Respondents were free to decline participation, not respond to any question or opt out completely at any given time during the interview without reprimands. Ethical approval was obtained for the study (UPTH/08/09).

\subsection{Study Design}

The target group of this investigation consisted of males attending urology primary care clinics and units in primary, secondary and tertiary healthcare institutions in the Niger Delta Region.

Criteria for Selection: The investigation utilized self- reporting measures and is based on findings from 2290 men who attended urology clinics in the participating healthcare institutions. They were questioned about their reasons for seeking for healthcare. A total of 75 cases met the inclusion criteria in the randomized follow-up study while 2215 cases met the exclusion criteria.

Criteria for Inclusion: Participants who presented with signs and symptoms of urologic dysfunctions including testicular cancer, infertility and erectile dysfunctions, some admitted to smoking marijuana on a casual or regular basis. Of the 75 of the cases who were included in the randomized follow-up study, 40 presented with the signs and symptoms of testicular cancer, infertility and erectile dysfunctions, these formed the intervention group; while 35 presented with benign carbuncles and rashes to the testes, they formed the control group.

Criteria for Exclusion: Participants who presented with urologic dysfunctions, prostrate problems and sexually transmitted diseases and denied smoking marijuana, absenteeism and inability to follow through in the course of the study were excluded.

Diagnosing Technique Utilized

- A physical examination typically reveals a firm lump (mass) in one of the testicles.

- Scanning /Ultrasound of scrotum reveals marked diminished size in the testes (scrotal shrinking)

- A physical examination typically reveals breast buds that is grossly enlarged (gynecomastia),

- Blood tests for tumor markers: alpha fetoprotein (AFP) and biopsy

- Spermicidal analysis for lowered sperm count, oligospermia and poor sperm motility was noted in heavy marijuana smokers

Statistical Analysis: The statistical package used was SPSS 12. Values were expressed in simple percentages. Chi-square test was used for test of significance.

\section{Result}

The socio-demographic distributions of 75 participants are given in Table 1. Statistical significant difference was found between the groups regarding to age, education and profession $(p>0.05)$. An association was observed between marijuana use and the occurrence of adverse effects on the human endocrine and reproductive systems and nonseminoma testicular cancer in particular $(p>0.05)$. Those who used marijuana weekly or who have had exposure to marijuana since adolescents had twice the testicular deficiencies, erectile dysfunction, infertility and cancer risk when compared to men who smoked a couple of times and those who never smoked marijuana (Table 2).

Table 1. Socio-Demographic and screening guidelines of Participants

\begin{tabular}{|c|c|c|c|}
\hline Variables & $\begin{array}{l}\text { Intervention } \\
\text { Group } \\
\end{array}$ & Control Group & $\mathrm{P}$ \\
\hline Age & $\mathrm{NO} / \% \mathrm{~N}=40$ & $\mathrm{NO} / \% \mathrm{~N}=35$ & \\
\hline$\leq 20$ & $2(5 \%)$ & $2(5.7 \%)$ & 1.000 \\
\hline $21-26$ & $7(17.5 \%)$ & $3(8.5 \%)$ & .206 \\
\hline $27-32$ & $11(27.5 \%)$ & $8(22.8 \%)$ & .491 \\
\hline $33-38$ & $9(22.5 \%)$ & $6(17 \%)$ & .439 \\
\hline $39-44$ & $6(15 \%)$ & $7(20.00 \%)$ & .782 \\
\hline$\geq 45$ & $5(12.5 \%)$ & $9(25.7 \%)$ & .285 \\
\hline Education & $\mathrm{NO} / \% \mathrm{~N}=\mathbf{4 0}$ & $\mathrm{NO} / \% \mathrm{~N}=35$ & \\
\hline Illiterates & $7(17.5 \%)$ & $6(17 \%)$ & .782 \\
\hline Primary education & $9(22.5 \%)$ & $10(28.6 \%)$ & .819 \\
\hline Secondary education & $15(37.5 \%)$ & $12(34 \%)$ & .564 \\
\hline Tertiary education & $9(22.5 \%)$ & $9(22.5 \%)$ & 1.000 \\
\hline Profession/Occupation & $\mathrm{NO} / \% \mathrm{~N}=\mathbf{4 0}$ & $\mathrm{NO} / \% \mathrm{~N}=35$ & \\
\hline Unemployed & $11(27.5 \%)$ & $9(25.7 \%)$ & .655 \\
\hline Self Employed & $16(40 \%)$ & $11(31.4 \%)$ & .336 \\
\hline Civil servants & $13(32.5 \%)$ & $15(42.8 \%)$ & .705 \\
\hline $\begin{array}{c}\text { Risk Factor Potentials } \\
\text { Variables } \\
\end{array}$ & $\begin{array}{c}\text { Intervention } \\
\text { Group } \\
\text { NO/\% N=40 }\end{array}$ & $\begin{array}{c}\text { Control } \\
\text { Group } \\
\text { NO/\% N=35 }\end{array}$ & \\
\hline Family history of TC & $3(7.5 \%)$ & $6(17 \%)$ & .317 \\
\hline $\begin{array}{l}\text { Lump or swelling in } \\
\text { either testicles }\end{array}$ & $6(15 \%)$ & $15(42.9 \%)$ & .050 \\
\hline $\begin{array}{c}\text { Previous injuries to the } \\
\text { testicles }\end{array}$ & $3(7.5 \%)$ & $10(28.6 \%)$ & .052 \\
\hline $\begin{array}{c}\text { Previous lump to the } \\
\text { testicles }\end{array}$ & $2(5 \%)$ & $6(17.1 \%)$ & .157 \\
\hline $\begin{array}{l}\text { Childhood Hx of un- } \\
\text { descended testicles }\end{array}$ & $1(2.5 \%)$ & $1(2.9 \%)$ & 1.000 \\
\hline $\begin{array}{c}\text { History of previous } \\
\text { cannabis use }\end{array}$ & $16(40 \%)$ & $0(0 \%)$ & 0.000 \\
\hline $\begin{array}{l}\text { History of present } \\
\text { cannabis use }\end{array}$ & $24(60 \%)$ & $0(0 \%)$ & 0.000 \\
\hline
\end{tabular}

TC Testicular cancer Hx History 
Table 2. Frequency/age of onset of Cannabis use in study participants

\begin{tabular}{|c|c|c|c|}
\hline Frequency & $\begin{array}{c}\text { Intervention } \\
\text { Group } \\
\mathrm{NO} / \% \mathrm{~N}=40\end{array}$ & $\begin{array}{c}\text { Control } \\
\text { Group NO/\% } \\
\mathrm{N}=35\end{array}$ & $\mathbf{P}$ \\
\hline Once to twice daily & $20(50 \%)$ & $0(0 \%)$ & 0.000 \\
\hline Once to twice weekly & $11(27.5 \%)$ & $0(0 \%)$ & 0.000 \\
\hline Once monthly & $5(8 \%)$ & $0(0 \%)$ & 0.000 \\
\hline $\begin{array}{c}\text { Once in } 6 \text { months or } \\
\text { yearly }\end{array}$ & $4(19 \%)$ & $0(0 \%)$ & 0.000 \\
\hline $\begin{array}{l}\text { Casual smokers } 10 \text { to } \\
20 \text { times in life time }\end{array}$ & $20(50 \%)$ & $0(0 \%)$ & 0.000 \\
\hline $\begin{array}{l}\text { Started smoking dur- } \\
\text { ing adolescence }\end{array}$ & $26(65 \%)$ & $0(0 \%)$ & 0.000 \\
\hline $\begin{array}{l}\text { Started smoking as } \\
\text { young adult }\end{array}$ & $12(30.5 \%)$ & $0(0 \%)$ & 0.000 \\
\hline $\begin{array}{l}\text { Started smoking in } \\
\text { middle age }\end{array}$ & $2(5 \%)$ & $0(0 \%)$ & 0.000 \\
\hline $\begin{array}{c}\text { Smokes cigarettes } \\
\text { occasionally }\end{array}$ & $12(30 \%)$ & $2(5.7 \%)$ & 0.008 \\
\hline $\begin{array}{l}\text { Drinks alcohol occa- } \\
\text { sionally }\end{array}$ & $10(25 \%)$ & $10(28.8 \%)$ & 1.000 \\
\hline \multirow{2}{*}{\multicolumn{4}{|c|}{$\begin{array}{rr}\text { Presenting } & \text { Symptoms } \\
\text { Study } & \text { Participants } \\
\end{array}$}} \\
\hline & & & \\
\hline Variables & $\begin{array}{c}\text { Intervention } \\
\text { Group } \mathrm{No} / \% \\
\mathrm{NO}=40\end{array}$ & $\begin{array}{l}\text { Control Group } \\
\mathrm{NO} / \% \mathrm{~N}=35\end{array}$ & \\
\hline $\begin{array}{l}\text { Discomfort or pain in } \\
\text { the testicle }\end{array}$ & $19(47.5 \%)$ & $10(28.6 \%)$ & .095 \\
\hline $\begin{array}{l}\text { Feeling of heaviness in } \\
\text { the scrotum }\end{array}$ & $23(57.5 \%)$ & $6(17 \%)$ & ,002 \\
\hline $\begin{array}{l}\text { Pain in the back or } \\
\text { lower abdomen }\end{array}$ & $7(17.5 \%)$ & $1(2.8 \%)$ & .034 \\
\hline $\begin{array}{l}\text { Change in the way } \\
\text { testicles feel }\end{array}$ & $20(50 \%)$ & $3(8.5 \%)$ & .000 \\
\hline $\begin{array}{l}\text { Diminished size of } \\
\text { testes reported }\end{array}$ & $8(20 \%)$ & $0(0 \%)$ & .000 \\
\hline $\begin{array}{c}\text { Benign carbuncles } \\
\text { mass }\end{array}$ & $0(0 \%)$ & $30(85.7 \%)$ & .000 \\
\hline Mass or lump detected & $11(27.5 \%)$ & $0(0 \%)$ & 0.00 \\
\hline $\begin{array}{l}\text { Mass/carbuncles trans } \\
\text { illuminate in flash light }\end{array}$ & $0(0 \%)$ & $30(85.7 \%)$ & 0.00 \\
\hline Erectile Dysfunction & $17(42.5 \%)$ & $3(8.5 \%)$ & .002 \\
\hline Rashes on testicles & $0(0 \%)$ & $28(80 \%)$ & 0.000 \\
\hline $\begin{array}{l}\text { Excess breast devel- } \\
\text { opment (gynecomas- } \\
\text { tia) }\end{array}$ & $14(35 \%)$ & $1(2.8 \%)$ & .001 \\
\hline $\begin{array}{l}\text { Infertility after } 2 \text { years } \\
\text { without contraceptives }\end{array}$ & $17(42 \%)$ & $2(5.7 \%)$ & .001 \\
\hline
\end{tabular}

\section{Discussion}

The result of this study postulates a link between cannabis use and urologic dysfunctions and an aggressive type of testicular cancer, called nonseminoma, which tends to strike younger men and accounts for 40 per cent of testicular cancer [7]. In this investigation, the frequent or long-term marijuana use significantly increased testicular cancer risk, particularly users who have had exposure to marijuana since adolescents, [Table 3]. This is in corroboration to previous studies which proposed that chronic marijuana use produces adverse effects on the human endocrine and reproductive systems[8]. The control group on the other hand did not use Cannabis and did not present as the intervention group [Table 3]. The testes have receptors for tetrahydrocannabinol (THC), the main psychoactive ingredient in cannabis, and the male reproductive system is known to naturally produce a cannabinoid-like chemical that is thought to protect against the disease[9]. The authors postulate that marijuana use may disrupt this anti-tumor effect, which could be another explanation for the possible link between the increased risks of urologic dysfunctions and testicular cancer in particular.

The knowledge which has been gained concerning the correlation between cannabis use and urologic dysfunction especially testicular cancer is of particular importance in view of the fact that the Niger delta's 'oil boom' has transcended into 'oil doom' due to the foreign exposure and the sudden eruption of enhanced purchasing powers, which indeed is creating more harm than good.

Excess breast development was evidenced in the intervention group but was not seen in the control group, who were not chronic marijuana users, a confirmation that cannabis has a great affinity for reproductive organs[10]. The progress in our understanding of marijuana use and the adverse effects on the human endocrine and reproductive systems especially testicular cancer is the direct result of the outburst of the epidemic; a disease that has been very rare in the men of African descent[11]. Respondents in the intervention group were heavy marijuana smokers with a chronic onset dating as far back as the adolescent years [Table 2]. This supports the hypothesis of previous studies which suggest a link between cannabis use and urologic anomalies [12].

As evidenced by Lue (2000), elevated risk of nonseminoma-type testicular cancer, in particular, was associated with marijuana use prior to age 18[13], as was noted in this study [Table 1]. The insight into the dynamics of cannabis use and the adverse effects on the human endocrine and reproductive systems especially testicular was made possible by the diagnostic techniques employed in this study. Thus various clinical syndromes have been identified and a rational basis for therapeutic intervention established. Another issue of concern in this study is the fact that long term marijuana smokers reported marked diminished size in their testes, from the intervention group, while the control group denied same [Table 2]. This is consistent with MacCoun and Reuter who argued that long term use of cannabis results in the shrinking of the testes[14].

Interestingly, infertility after two years of trial in marriage without use of contraceptives was also reported mainly from the intervention group who were the smokers of cannabis. Previous investigations evidenced that the THC in marijuana actually effects sperm negatively and literally makes them high. The sperm get "wired" and then literally burn out making it hard for them to achieve their ultimate destination. This may yet be another reason why marijuana is tied to reports of infertility (along with the decreased testosterone, LH and FSH of course)[15-18]. This could explain the high level of infertility noted in the intervention group [Table 3]

A stronger literature has identified an association between marijuana use and carcinogenesis. Additional studies are 
recommended to determine the generalizability of these results.

\section{Conclusions}

This well-conducted population-based case-control study on the effects of marijuana use on reproductive organs provided data on 75 male respondents, which allowed us to examine adverse effects it has on male reproductive organ. An association was observed between marijuana use and the occurrence of urological and reproductive dysfunctions; infertility, excess breast development (gynecomastia), marked diminished size in the testes (scrotal shrinking), and testicular cancer, showing a linkage between nonseminoma, an aggressive case that is idiosyncratic to cannabis which tends to strike younger men and accounts for 40 per cent of reproductive and urologic dysfunction. Even in the absence of any symptoms, the authors suggest that a decision to smoke marijuana recreationally is taking a chance with one's future health.

Further studies may help clarify the associated risk factors and the effects cannabis has on male reproductive organs. [Table 2] We suggest further work could be carried out in monitoring of urologic risk in men who smoke marijuana dating as far back as the teenage years.

\section{Limitations}

Several caveats are noteworthy. The investigators believe it is unlikely that a study of this magnitude could ever be conducted in Nigeria, given the level of knowledge deficits relatively common in the populace regarding the effects of marijuana use on urologic and reproductive system and institutionalized ethical constraints for research in human subjects.

Antagonisms from addicts, access to sites, bad roads, poor transportation facilities to and from primary healthcare centers and level of illiteracy were some of the limitation we encountered, and were partially overcome by providing a stipend of $=\mathrm{N}=500$ (equivalent to $\$ 5$ ) to each participant, to augment for transportation during each session.

Another limitation of this study is the small sample size, and therefore may not be a true reflection of the situation in the community. Additional studies are recommended to determine the generalizability of these results.

\section{REFERENCES}

[1] National comprehensive cancer network 2010. Clinical practice guidelines in oncology. Testicular cancer. v.2.

[2] Lee SY, Oh SM, Chung KH 2006. Estrogenic effects of marijuana smoke condensate and cannabinoid compounds.
Toxicol.Appl.Pharmacol.;214:270-278.

[3] Trabert B, Sigurdson A, Sweeney SS, McGlynn KA.2011 Marijuana use and testicular gem cell. Cancer; 117: 884-853

[4] Wenger T, Ledent C, Csernus V, Gerendai I. 2001 The central cannabinoid receptor inactivation suppresses endocrine reproductive functions. Biochem.Biophys.Res National Comprehensive Cancer Network. Clinical practice guidelines in Commun.;284 : 363-368.

[5] Dearnaley DP, Huddart RA, Horwich A.2001 Managing testicular cancer. BMJ.; 322: 1583-1588.

[6] Rosen RC.2001. Psychogenic erectile dysfunction. Classification and management. Urologic Clinics of North America.;28: 269-278.

[7] Screening for testicular cancer 2004. Update of the evidence for the U.S. Preventive Services Task Force. Agency for Healthcare Research and Quality. Accessed May 15, 2010.

[8] Wang H, Dey SK, Maccarrone M. Jekyll, Hyde 2006 Two faces of Cannabinoid signaling in male and female fertility. Endocr.Rev.;27:427-448.

[9] Einhorn LH. 2007. Testicular cancer. In: Goldman L, Ausiello D, eds. Cecil Medicine. 23rd ed. Philadelphia, Pa: Saunders Elsevier; chap 210.

[10] Daniels IR, Layer GT.2003. Testicular tumors presenting as gynaecomastia. Eur J Surg Oncol ;29:437-439

[11] National Institute for Clinical Excellence. 2002. Improving outcomes in urological cancers: the manual. September . Cancer service guidance. Available at http://www.nice.org.u k/guidance/CSGUC (accessed on 8 July 2011).

[12] Patsos HA, Hicks DJ, Greenhough A, Williams AC, Paraskeva C. 2005. Cannabinoids and cancer: potential for colorectal cancer therapy. Biochem.Soc.Trans.;33:712-714.

[13] Michaud PA, Berchtold A, Jeannin A, Chossis I, Suris JC. 2006. Secular trends in legal and illegal substance use among 16 to 20 year old adolescents in Switzerland. Swiss.Med Wkly.; $136: 318-326$.

[14] MacCoun R, Reuter P. 1997. Interpreting Dutch Cannabis policy: reasoning by analogy in the legalization debate. Science.;278:47-52.

[15] McGlynn KA, Devesa SS, Sigurdson AJ, Brown LM, Tsao L, Tarone RE. 2003. Trends in the incidence of testicular germ cell tumors in the United States. Cancer.;97:63-70.

[16] Lue TF. 2000. Erectile dysfunction. New Eng J Med; 342: 1802-1813.

[17] Shelley MD, Burgon K, Mason MD. 2002. Treatment of testicular germ-cell cancer: a Cochrane evidence-based systematic review. Cancer treatment review.; 28: 237-253.

[18] Feldman DR, Bosl GJ, Motzer RJ. 2008. Medical treatment of advanced testicular cancer. J Amer Med Asso.; 299: 672-684. 